\title{
VÁROSI FUNKCIÓJÚ KÖZPONTOK ÉS ELMÉLETI VONZÁSKÖRZETEIK AZ ALFÖLDÖN
}

\author{
(Urban Centres and their Theoretic Spheres of Influence in the \\ Great Hungarian Plain)
}

\section{KISS JÁNOS PÉTER-BAJMÓCY PÉTER}

Kulcsszavak:

Alföld, településhálózat, gravitációs modell, vonzáskörzet

Az Alföld terilletére az empirikus vonzáskörzet vizsgálatok mellett létjogosultsága van az elméleti úton lehatárolt vonzáskörzet vizsgálatoknak, igy a gravitációs modelleknek is. A sajátos telepuilési adottságok a mindennapi térkapcsolatokban és a kistérségi szintü vonzásviszonyok esetében egyaránt speciális problémákat okoznak. A valós vonzáskörzetek - ezt empirikus kutatások sora igazolja - igen összetettek, $s$ ehhez hozzajárulnak az elérhetöségi viszonyokat jelentösen befolyásoló nagyobb folyók és közlekedéshálózati adottságok is. A modellek eredményeként sikerült lehatárolni az alfóldi városaink elméleti vonzáskörzeteit, de emellett e lehatárolás számos következtetés levonására is lehetőséget nyújtott (vonzáskörzettel nem, vagy alig rendelkezô városok, valamint valódi vonzáscentrumok körének meghatározása, statisztikai kistérségek és városi vonzáskörzetek összehasonlítása, centrumtérségek és perifériák meghatározása).

A városok és „vidékük" közötti kapcsolatok, a városi vonzáskörzetek rendszerének empirikus feltárása és elemzése a gyakorlatban rendkívül nehéz feladat. E viszonyokat ugyanis igen sok és sokféle tényező alakítja egyidejüleg, amelyek megnyilvánulásai a valóságban rendkívül tömegesek, rendszeres statisztikai adatgyüjtés viszont többségükről nincsen, s az ezekről való információszerzés egyéb lehetőségei is meglehetősen korlátozottak, illetve idő- és költségigényesek (Beluszky 1974). A hierarchikus vagy funkcionális térkapcsolatok, vonzásviszonyok felderítése, az empirikus eredményekkel való összevetése érdekében így nagy szủkség van elméleti modellekre, teoretikus vonzáskörzetmeghatározásokra is. Ezek egyik, a nemzetközi szakirodalomban gyakran alkalmazott módszere a gravitációs analógián alapuló modellezés.

A gravitációs modellek alkalmazása révén egyszerủ matematikai apparátussal - és a számítógépek segítségével ma már gyorsan és könnyen - becsülhetö a különböző ágazati, illetve komplex vonzáskörzetek kiterjedése, sőt a vonzás intenzitásának elméleti értéke is számszerüsíthető. Az Alföld esetében különösen érdemesnek tủnt ennek az elméleti megközelítésnek az alkalmazása, hiszen a sajátos települési adottságok (nagyhatárú mezővárosok, óriásfalvak, ritka településhálózat, a közép- és kisfalvak hiánya, közigazgatási önállósággal nem rendelkező települések, tanyák) a 
Kiss János Péter - Bajmócy Péter: Városi funkciójú központok és elméleti vonzáskörzeteik az Alföldön.

Tér és Társadalom, 15. 2001. 1. 65-89. p.

66 Kiss János Péter - Bajmócy Péter

TÉT XV. évf. 2001 - 1

mindennapi térkapcsolatokban, illetve a területfejlesztés kistérségi egységeinek lehatárolásakor és múködtetésekor egyaránt speciális problémákat okoz, amihez hozzájárulnak az elérhetőségi viszonyokat jelentösen befolyásoló természeti korlátok - elsősorban a nagyobb folyók - és közlekedéshálózati adottságok is.

\section{A modellek adatbázisa, az alkalmazás módszertani problémái az Alföldön}

A newtoni tömegvonzás analógiáján alapuló gravitációs modellben a feltételezett vonzásközpontok „tömegének” és a tölük mért távolság valamely rögzített hatványának hányadosait összehasonlítva elméletileg minden településröl egyértelmüen eldönthetö, hogy mely központ ,,vonzóereje” hat rá a legnagyobb mértékben, így bármely terület konkrét határokkal rendelkező vonzáskörzetekre tagolható. A módszer alkalmazásának alapkérdése az, hogy ,a gravitációs összefüggés paramétereit úgy határozzuk meg, hogy a modell által szolgáltatott, pontok közötti elméleti vonzáserösség és a területi kapcsolatok valós mértéke lehetőleg jól közelítse egymást" (Nemes Nagy-Piros 1984, 172). A gyakorlatban az eredmények interpretálhatóságának kulcskérdései a központok körének, a hozzájuk rendelt „tömeg” konkrét tartalmának, az alkalmazott távolságmutatónak és a képletben szereplö hatványkitevönek a megfelelő kiválasztása.

„Alföldiként” összesen 794 település került vizsgálatunk körébe: Bács-Kiskun, Békés, Csongrád, Jász-Nagykun-Szolnok, Hajdú-Bihar és Szabolcs-Szatmár-Bereg megye valamennyi városa és községe, Borsod-Abaúj-Zemplén, Heves és Pest megye déli részének települései, valamint a Duna bal partján fekvő Baranya megyei Homorúd. Közülük 1999. január 1-jén kereken 100 településnek volt városi jogállása, ám teljes értékü térségi központi szerepkört korántsem mindegyikük tölt be, $s$ egy részük alig rendelkezik központi funkciókkal. Ennek ellenére nem szelektáltuk öket elözetesen, hanem - a vizsgálat első fázisában - valamennyiüket vonzásközpontként vettük figyelembe. A száz alföldi város mellett - a többi városhoz képest kiemelkedően nagy, ezért a vizsgálat eredményeit jelentösen torzitani képes Budapestet kivéve - figyelembe vettük azon magyarországi városokat is, amelyek maguk ugyan már nem tartoznak a fenti módon elhatárolt Alföldhöz, de gravitációs vonzásuk alföldi településekre is kiterjedhetett. (Összesen tíz város került ebbe a körbe: Sátoraljaújhely, Sárospatak, Szerencs, Tokaj, Miskolc, Eger, Gyöngyös, Ráckeve, Dunaföldvár és Dunaújváros.) Ilyen módon tehát nemcsak az elméleti vonzásterületek elhatárolása, hanem a központok körének kiválasztása is a lehetséges objektivitással történt.

A központok „tömegének” a számos lehetőség - pl. a városok ellátó intézményeinek száma, költségvetése stb. - közül a népességszámot tekintettük (1997. dec. 31-ei lakónépesség), mert ez kellően differenciált, és a szakirodalmi adatok (Beluszky 1967; Dicken-Lloyd 1984; Meyer-Huggett 1981) szerint a 
Kiss János Péter - Bajmócy Péter: Városi funkciójú központok és elméleti vonzáskörzeteik az Alföldön.

Tér és Társadalom, 15. 2001. 1. 65-89. $p$.

TÉT XV. évf. 2001 = 1

Városi funkciójú központok...

67

központok funkcionális fejlettsége, az általuk kínált szolgáltatások választéka nagyjából arányos a népességszámukkal.

A városok és a vonzott települések közötti távolság szerepe a gyakorlatban is alapvető fontosságú, hiszen a vonzáskapcsolatokat leggyakrabban valamilyen (fizikai) forgalomáramlás testesíti meg (Nemes Nagy-Piros 1984). Az általunk elméletileg vizsgált vonzáskörzetek a valóságban annak alapján léteznek, hogy mely centrumokat keresik fel a különbözö településeken élö emberek a szolgáltatóellátó funkciók egy bizonyos körének („középfokú”, „kistérségi”, „városi alap”szolgáltatások) igénybevétele érdekében. A távolság mutatójának helyes megválasztása azért is alapvető fontosságú, mert ennek hatása a modell számítása során hatványozottan jelenik meg.

Modellünkben a távolságot a településközpontok közötti legrövidebb út nagyságával fejeztük ki, mert a központok megközelíthetőségében ma már a közúti közlekedésnek van elsödleges szerepe (személygépkocsival vagy menetrend szerinti autóbusszal), így a központokban megtalálható szolgáltatások elérhetöségét a gyakorlatban leggyakrabban a közúti távolság befolyásolja. ${ }^{1}$ Mindez természetesen nem minden esetben igaz. Az adott funkciók sajátosságaitól vagy az igénybe vevők társadalmi csoportjától függően elötérbe kerülhet a tömegközlekedéssel vagy személygépkocsival történő utazás idö- és költségigénye is.

A távolság hatványkitevője elméletileg tetszöleges pozitív valós szám lehet. Kiválasztása mindig a vizsgált probléma függvénye, azaz az adott funkció, illetve társadalmi csoport sajátosságaitól függően eltéró értékeket érdemes választani (Nemes Nagy-Piros 1984). ${ }^{2}$ A komplex elméleti vonzáskörzetek meghatározásának célja, illetve a központok és a többi település közötti, a különféle funkciók által generált áramlások mértékére vonatkozó empirikus adatok hiánya azonban e téren is absztrakciót tesz szükségessé, ezért ezekben az esetekben a kitevő választását elsősorban az határozza meg, hogy mekkora az egységnyi területre jutó központok száma, illetve, hogy mekkora e központok tömegének a szóródása. Korábbi vizsgálatunkban (Bajmócy-Kiss 1999) a hét magyarországi régióközpont vonzásterületének kiszámításához a hetedik, a 19 megyeszékhely esetében pedig a negyedik hatvány választása bizonyult a legcélszerübbnek. (A szomszédos egész kitevőjü hatványokkal számított gravitációs alapú területi beosztások között viszonylag kicsik a különbségek, így a potenciális kitevők között a leggyakrabban elégséges az egész számokat figyelembe venni.)

$\mathrm{Az}$ alföldi városok elméleti gravitációs vonzásterületét a kettes, a hármas és a négyes hatványkitevők felhasználásával egyaránt meghatároztuk. ${ }^{3}$ A klasszikus newtoni modellben a távolság négyzete szerepel, ezt azonban jelen esetben el kellett vetnünk, mivel a, legnagyobb népességszámú központok irreálisan nagy „,vonzásterülethez” jutottak volna, ezzel mintegy „körbevéve” számos, vonzásterület nélkül maradó kisebb várost. A hármas és a négyes kitevőt alkalmazva már nem adódott ilyen probléma. 
Kiss János Péter - Bajmócy Péter: Városi funkciójú központok és elméleti vonzáskörzeteik az Alföldön. Tér és Társadalom, 15. 2001. 1. 65-89. p.

68 Kiss János Péter-Bajmócy Péter TÉT XV. évf. 2001

1. ÁBRA

Az 1. modell szerinti körzetbeosztás (minden város vonzásközpont)

(Gravitation Areas by Model 1. - Each Town is Gravitation Centre)

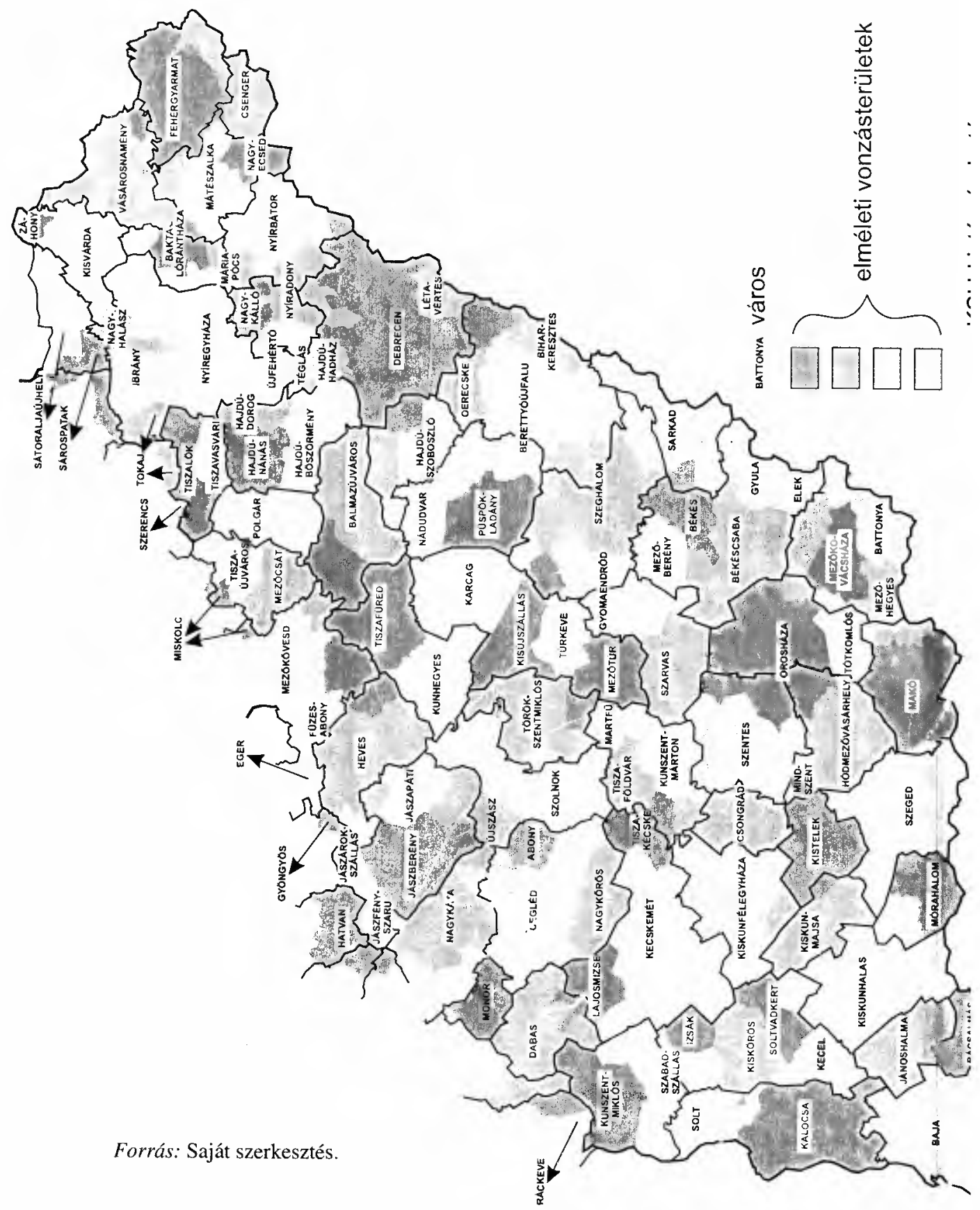


Kiss János Péter - Bajmócy Péter: Városi funkciójú központok és elméleti vonzáskörzeteik az Alföldön.

Tér és Társadalom, 15. 2001. 1. 65-89. p.

Városi funkciójú központok...

69

E két számítás eredménye között leginkább ott adódtak különbségek, ahol igen eltérő népességủ központok voltak egymással szomszédosak. A két lehetöség közül végül a távolság köbének figyelembevétele mellett döntöttünk, mert - mivel az alföldi városok viszonylag sürủn töltik ki a teret - a negyedik hatvánnyal számolva a központok nagyságának szerepe már túl kicsinek bizonyult a távolságokkal szemben.

\section{A városi jogállású települések elméleti vonzásterületei - avagy van-e „vidéke" minden városnak?}

A valamennyi várost vonzáscentrumként figyelembe vevő 1. modellünkben kialakult „körzetek” területe, népessége, illetve az öket alkotó települések száma igen nagy szóródást mutat (1. ábra). Kilenc városnak (Hajdúnánás, Hajdúdorog, Hajdúböszörmény, Nádudvar, Túrkeve, Tiszavasvári, Abony, Izsák, Mindszent) egyetlen vonzott faluja sincs, míg az aprófalvas Szabolcs-Szatmár-Bereg megyében több városhoz is $20-40$ aprófalu kapcsolódik. A legnagyobb összlakosságú falusi vonzásterülete általában természetesen a legnépesebb centrumoknak van (a megyeszékhelyek, Baja, Cegléd), ám figyelemre méltó, hogy mindannyiukat megelőzi az alig 18 ezres Kisvárda, és Vásárosnamény, Fehérgyarmat, Berettyóújfalu körzete is az elsők között szerepel. Mindez Szatmár-Beregnek és a bihari térségnek az alfölditől elütö településszerkezetét és centrumhiányos jellegét bizonyítja.

A modellben kapott vonzásterületek alakja kevéssé közelíti a geometriailag megszerkeszthetö egységekét. A gravitációs vonzáskörzetek ugyanis elméletileg körívekkel határolt síkidomok ${ }^{4}$, ám ahhoz, hogy mindez a településterületekre osztott térképen is jól kirajzolódjon, arra lenne szükség, hogy a községek viszonylag sürün és egyenletesen helyezkedjenek el. Az Alföldön azonban a ritka településhálózat, a sok nagyhatárú település (és ennek következtében az átlagosan mindössze hét településböl álló egységek), illetve a politikai, természeti határok miatt ez a szabályosság csak ritkán ismerhetö fel a „vonzáskörzeteket” ábrázoló térképen.

További szabálytalanságot okoz, hogy a légvonaltávolságok helyett a közúti elérhetőséggel számoltunk, mert így a közúthálózat sajátosságai is befolyásolják a vonzáskörzetek kialakulását. A közúti összeköttetés hiánya, avagy kedvezötlen nyomvonala jelentősen megnehezitheti egyes központok elérhetöségét, söt akár alapvetően meghatározhatja egyes települések ,hovatartozását”. E hatás mértékének kiderítése érdekében modellünket a légvonaltávolságokat alapul véve is elkészítettük (1/b. modell). Így a falvak tizede került más város vonzásterébe. A 74 ilyen település (2. ábra) legnagyobb részénél a folyók (illetve a rajtuk átvezetỏ állandó hidak hiánya) okozták az eltérést. Elsősorban a Tisza (31 eset) és a Szamos (8) rossz átjárhatósága idéz elő ilyen problémákat. 
Kiss János Péter - Bajmócy Péter: Városi funkciójú központok és elméleti vonzáskörzeteik az Alföldön. Tér és Társadalom, 15. 2001. 1. 65-89. $p$.

70 Kiss János Péter - Bajmócy Péter

TÉT XV. évf. 2001

\section{2. ÁBRA}

A közúti, illetve légvonal-távolságokkal számított gravitációs modellek eltérései (Differences Between Gravitation Models Based on Road and Linear Distances)

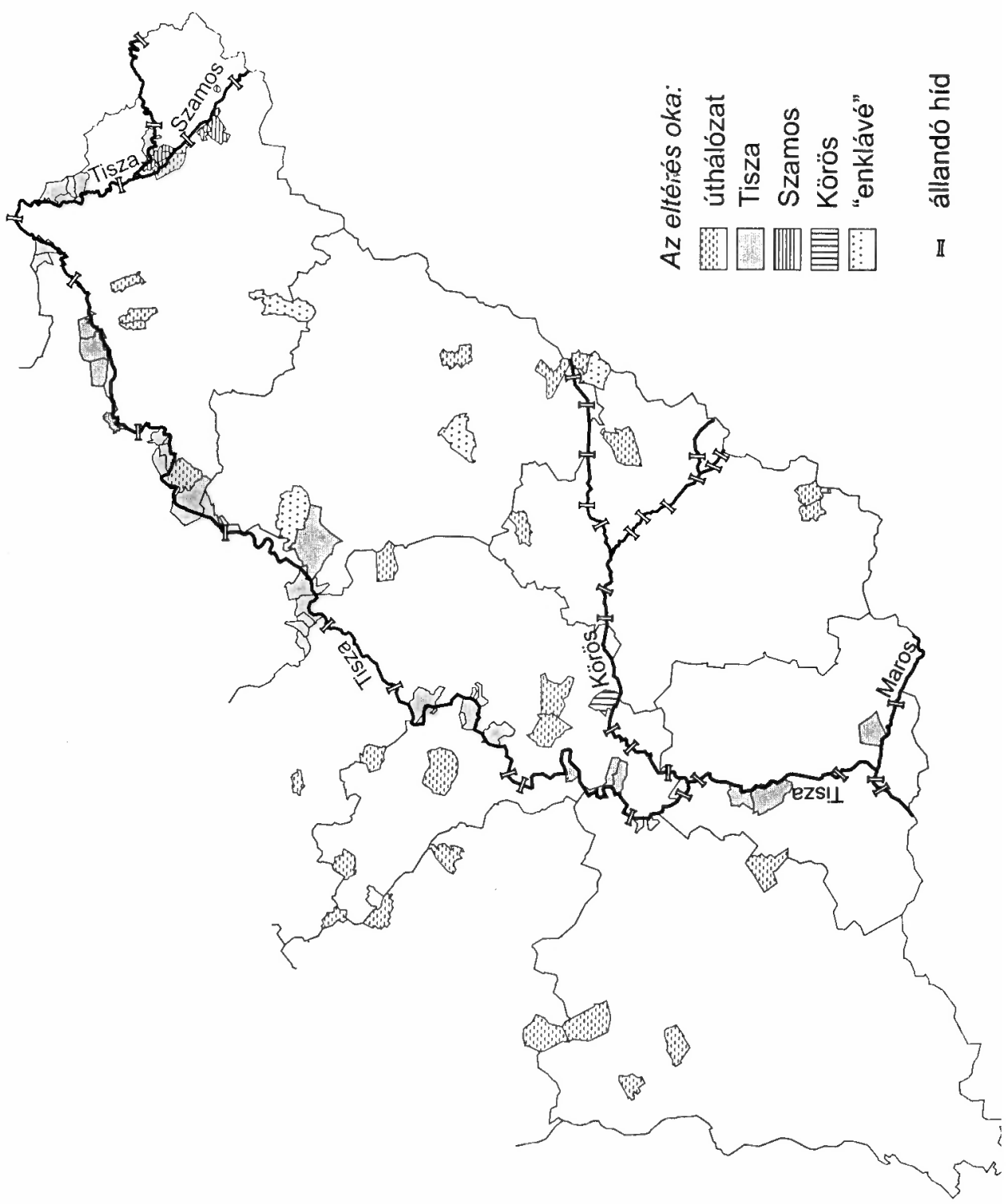

Forrás: Saját szerkesztés. 
Kiss János Péter - Bajmócy Péter: Városi funkciójú központok és elméleti vonzáskörzeteik az Alföldön.

Tér és Társadalom, 15. 2001. 1. 65-89. p.

TÉT XV. évf. 2001 - 1

Városi funkciojủ központok...

71

$\mathrm{Az}$ esetek másik jelentős csoportjában (29 alkalommal) közvetlen módon az úthálózat kiépítetlensége vagy vonalvezetése idézi elö, hogy a fekvéséböl következö helyett más központhoz kapcsolódik egy-egy falu. Az ábrán feltüntettük azt a négy községet is, amelyeket nem a legnagyobb vonzóerejü, hanem az utána következö centrumhoz soroltunk be. Erre azért volt szükség, mert célunknak megfelelöen arra törekedtünk, hogy területileg egybefüggö, kompakt vonzásterületeket határoljunk le, azaz kizártuk azokat az eseteket, amikor a vonzásközpontba egy másik vonzáskörzethez tartozó település központi belterületén keresztül vezetett volna a legrövidebb út, s így az érintett falvak „enklávék” lettek volna. A 74 település elhelyezkedését tekintve szembeötlő, hogy többségük periférikus elhelyezkedésủ (megye- vagy országhatár mentén fekszik), s zömmel aprófalvakról van szó (lakosságuk együttesen alig haladja meg a százezer föt).

Kisérlet a térségi szerepkörü városok és vonzásterületeik elhatárolására

Az elözőekben felsorolt okok is egyértelmủen arra utaltak, hogy a valamennyi városi jogállású települést vonzásközpontként tekintő modell nem feleltethető meg a valódi, funkcionális kistérségi kapcsolatrendszereknek (Becsei 1996), ezért szükség volt a központként számba vett városok körének csökkentésére és ennek megfelelöen egy új modell felállítására. Ezt valószínüsítette már az is, hogy az 1. modellben a saját határán túli vonzásterülettel nem rendelkező tíz városon kívül további 37-nek is csak 1-3 község alkotja a gravitációs vonzásterïletét, azaz az alföldi városok fele nem rendelkezik a hagyományos értelemben vett „térséggel”, ${ }^{\text {, }}$ és többségük saját népessége sem túl nagy. Néhány kisebb településre kiterjedő, alapellátásra, illetve egy-két középfokú funkcióra korlátozódó mikroközponti szerepkörrel viszont az empirikus vizsgálatok tanúsága szerint több község is rendelkezik. Így - pusztán eltérő közigazgatási státusuk miatt - indokolatlan öket megkülönböztetni a hasonló szerepú városoktól, amelyek a középfokú ellátó funkciók nagyobb részében - számos empirikus vizsgálat megállapításai szerint - maguk is valamely nagyobb központ vonzásterületének részét képezik. A KSH kistérségi rendszere sem a városi jogállású települések alapján szerveződött, hiszen az általunk vizsgált terület 100 városa 55 statisztikai kistérség között oszlik meg.

A legfontosabb érv azonban, amely a városi jogállású települések és a tényleges vonzásközpontok megkülönböztetését indokolja, az, hogy a gyakorlati tapasztalatok és a vonatkozó irodalom megállapításai (Beluszky 1967) szerint a középfokú központi funkciók minél teljesebb körének megtelepedéséhez és gazdaságos fenntartásához - ami egy települést végső soron vonzásközponttá emel - szükség van arra, hogy a központ és vonzáskörzete mérete együttesen elérjen egy minimális értéket, ,kritikus tömeget”. Ez a határérték, bár a körzet társadalmi összetételétől 
Kiss János Péter - Bajmócy Péter: Városi funkciójú központok és elméleti vonzáskörzeteik az Alföldön. Tér és Társadalom, 15. 2001. 1. 65-89. p.

függően többé-kevésbé ingadozik, alapvetően az ellátott lakosság számával arányos - márpedig első modellünkben sok városi „körzet” népessége igen alacsony volt.

A vonzáscentrumként figyelembe vett városok körének meghatározására több elméleti lehetőség is kínálkozott. Kézenfekvő lenne például egy adott városcsoport önkényes kiválasztása: minden KSH-kistérség legnépesebb városát, az $n$ legnagyobb népességü várost, vagy akár a - valamely empirikus felmérés adatai szerint - középfokú központi szerepkört betöltő városokat is ki lehetne jelölni vonzásközpontnak. Objektívebb és tudományos szempontból is többet mondó azonban, ha nem efféle - a modellezés logikáján kivül eső - meggondolás alapján, hanem az első modell eredményeiből kiindulva szelektálunk. Így ugyanis nemcsak a városok, hanem a vonzáskörzetek (tehát valamennyi település) jellemzőit együttesen vehetjük figyelembe, márpedig a városok funkcionális fejlettsége és ebböl eredö vonzásközpont mivolta - mint arra az elöbbiekben utaltunk - nem saját méretüktöl, hanem az ellátott terület (vonzáskörzet) egészének nagyságától függ. A szelekció alapja lehet a vonzáskörzet településeinek száma, összlakosságának száma, a vonzott (központon kívüli) lakosság száma, a központ lakosságának és a vonzott lakosságnak az aránya stb., illetve ezek valamilyen kombinációja. A funkcionális vonzáskörzetek kialakulása szempontjából ezek közül - a korábbiakban elmondottak értelmében - a körzet lakosságszámának van meghatározó szerepe. Új modellünkben ezért alapvetően úgy volt célszerủ csökkenteni a központok számát, hogy a kialakuló valamennyi elméleti vonzásterület népessége érjen el egy meghatározott nagyságot. Az egyes szerepkörök ${ }^{6}$ minimális „piacmérete” azonban jelentösen különbözik egymástól. Számunkra így egy olyan határérték kiválasztása volt a cél, amely a középfokú pontosabban: a funkcionális kistérségek létezésében érdemi szerepet játszó - városi funkciók minél nagyobb részének minimális piacmérete közelében van. ${ }^{7}$

Mindezek alapján 2. modellünkben a vonzásterületek minimális összlakosságát tapasztalati adatokat és szakirodalmi utalásokat felhasználva - 25 ezer föben határoztuk meg. Az l, modellben ezt el nem ért körzetek minden egyes települését (a várost is) ahhoz a központhoz soroltuk, amely a többiek közül a legnagyobb erövel vonzotta. Mindezt azonban lépésenként volt célszerú elvégezni, hiszen így - a kieső körzetek településeit átvéve - olyan központok vonzáskörzete is átléphette a 25 ezres határértéket, amelyeké az eredeti modellben nem érte el ezt. A gyakorlatban mindez úgy történt, hogy elöször a legkisebb összlakosságú körzetet osztottuk fel a többi város között, majd a többi - immár részben módosult nagyságú - vonzáskörzet közül a legkisebbel ismételtük meg ugyanezt, és e lépéseket addig folytattuk, amíg a fennmaradt legkisebb körzet lakossága is meghaladta a határértéket. (Azon központok esetében, amelyek az Alföldön kívüli vonzott településekkel is rendelkeztek az 1 . modellben, természetesen a teljes vonzásterület lakosságát figyelembe vettük a szelekció során.) 
Kiss János Péter - Bajmócy Péter: Városi funkciójú központok és elméleti vonzáskörzeteik az Alföldön. Tér és Társadalom, 15. 2001. 1. 65-89. p.

TÉT XV. évf. 2001 - 1

Városi funkciójú központok... 73

\section{3. ÁBRA}

A 2. modell szerinti körzetbeosztás (48 vonzásközpont)
(Gravitation Areas by Model 2. 48 Gravitation Centres)
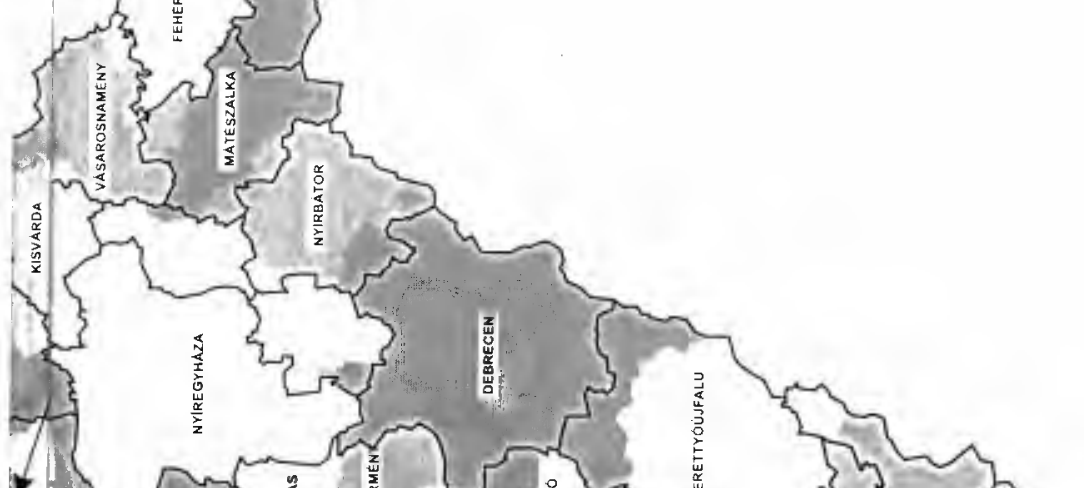

sits

.

s

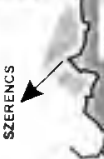

善

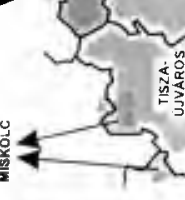

Forrás: Saját szerkesztés.
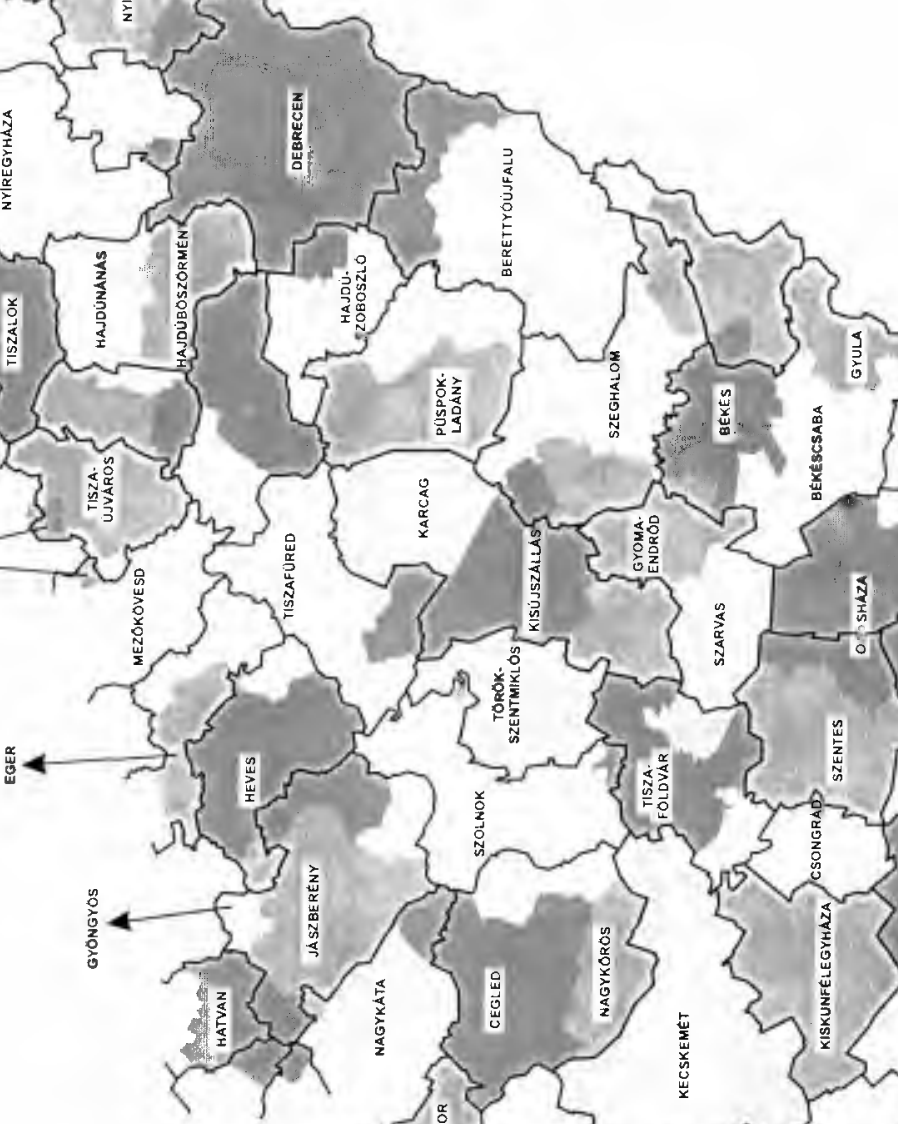
Kiss János Péter - Bajmócy Péter: Városi funkciójú központok és elméleti vonzáskörzeteik az Alföldön. Tér és Társadalom, 15. 2001. 1. 65-89. p.

74 Kiss János Péter - Bajmócy Péter

TÉT XV. évf. 2001 - 1

Az ismertetett módon elóállitott 2. modellben 48 alföldi és 8 külső, összesen 56 központ vonzáskörzete fedi le az általunk vizsgált térséget (3. ábra, 1. táblázat). A modell alapján tehát ezek azok a települések, amelyek nagy valószinűséggel funkcionális értelemben is teljes értékủ városoknak tekinthetők. Feltủnő, hogy az igazgatási városállománynak alig fele tartozik ebbe a körbe.

Különösen nagy az aránytalanság Bács-Kiskun (17-bỏl 6), Hajdú-Bihar (16-ból 6) és Szabolcs-Szatmár-Bereg (17-böl 7) megyében.

Az alföldi központok közül hatnak vannak az Alföldön kívüli vonzott települései is (Nyíregyházának 1, Nagykátának 2, Bajának 3, Monornak 8, Mezőkövesdnek 9 és Hatvannak 19). A központok átlagos lélekszáma közel 35 ezer fö, ám rendkívül nagyok a különbségek (a két szélsöséget a 210 ezres Debrecen és a hatezres Tiszalök képviseli, $\mathrm{s}$ a relatív szórás ${ }^{8}$ is igen magas, 1,18 értékü). A nagy többséget a 10-30 ezres városok jelentik (a medián értéke 19 ezer körüli). Mivel a fennmaradó központok körét nem a saját, hanem vonzáskörzetuik nagysága alapján határoztuk meg (aminek kialakulását a városok egymáshoz viszonyított elhelyezkedése is befolyásolta), modellünkben vonzásközpontok maradhattak egyes kisebb városok is. Ezek egy része a leginkább falusias térségekben, nagyobb városok vonzásától nem érintett perifériákon található (Fehérgyarmat, Vásárosnamény, Nyírbátor, Szeghalom, Berettyoújfalu, Tiszaföldvár, Tiszafüred, Heves, Nagykáta), más részük viszont sajátosan alföldi, szomszédos kisvárosokból álló településegyüttes legnagyobb tagjaként tölt be vonzásközponti szerepet (Mezőkovácsháza, Kiskőrös, Kisújszállás, Tiszaföldvár, Hajdúnánás). Zömmel persze a nagyobb városok maradtak meg a központok között a szelekció után: a 15 ezer fönél nagyobb népességủek közül csak Mezőtúr (19,3 ezer), Balmazújváros ( 18,3 ezer) és Abony (15,2 ezer) nem rendelkezett 25 ezer föt meghaladó népességszámú gravitációs vonzáskörzettel, míg a 10 ezresnél kisebb városok közül csak Tiszalök, Mezőkovácsháza, Fehérgyarmat és Vásárosnamény körzete érte el a kritikus méretet.

Érdemes rámutatni arra is, hogy a vizsgált területen 1986 óta várossá nyilvánított 58 település közül csak nyolcnak (Mezökovácsháza, Püspökladány, Tiszaföldvár, Dabas, Monor, Nagykáta, Gyomaendrőd, Tiszalök) van népesebb vonzáskörzete. ${ }^{9}$ Mindez azt jelenti, hogy az újonnan várossá nyilvánított települések többségéröl nehezen feltételezhető, hogy a (középfokú) központi funkciók teljes körével vagy akár csak azok nagyobb részével is rendelkezik, ezért ebből a szempontból megkérdőjelezhető a tömeges várossá nyilvánítások (és a további hasonló tervek) indokoltsága.

A választott módszer jellegéböl adódóan - a városok elhelyezkedésének nagy szerepe miatt - elöfordulhattak olyan esetek, amikor egy vonzáskörzetnek nem a központ a legnagyobb települése. Ez azonban nem bizonyult túl gyakorinak. Az 1. modellben három ilyen beosztás adódott (Baktalórántháza körzetében Vaja, Máriapócséban Ófehértó, Tokajéban Rakamaz nagyobb a központi városnál). 
Kiss János Péter - Bajmócy Péter: Városi funkciójú központok és elméleti vonzáskörzeteik az Alföldön.

Tér és Társadalom, 15. 2001. 1. 65-89. $p$.

TÉT XV. évf. 2001

Városi funkciójú központok... 75

\section{TÁBLÁZAT}

A második modellben kialakult körzetek néhány jellemzō adata (Some Characteristics of the Districts Emerged from the Second Model)

\begin{tabular}{|c|c|c|c|c|c|c|c|}
\hline \multirow{2}{*}{$\begin{array}{c}\text { A vonzásközpont } \\
\text { neve }\end{array}$} & \multirow[b]{2}{*}{$\begin{array}{r}\text { lakónépessége } \\
\text { 1998. jan. I }\end{array}$} & \multicolumn{4}{|c|}{ A vonzott települések } & \multicolumn{2}{|c|}{ A vonzáskörzet } \\
\hline & & száma & $\begin{array}{l}\text { ebböl } \\
\text { város }\end{array}$ & $\begin{array}{r}\text { összlakossága } \\
\text { 1998. jan. I }\end{array}$ & $\begin{array}{l}\text { súlyozott } \\
\text { átlagos } \\
\text { távolsága }\end{array}$ & $\begin{array}{r}\text { összlakossága } \\
\text { 1998. jan. } 1\end{array}$ & $\begin{array}{c}\text { összterülete, } \\
\mathrm{km}^{2}\end{array}$ \\
\hline Kecskemét & 105215 & 23 & 5 & $8 7 \longdiv { 1 0 7 }$ & 27,9 & 192322 & 2157,8 \\
\hline Baja* & 37187 & 32 & 2 & 71085 & 23,4 & 108272 & 1859,0 \\
\hline Kalocsa & 17997 & 17 & & 30972 & 14,0 & 48969 & 852,3 \\
\hline Kiskörös & 14715 & 10 & 2 & 29727 & 12,2 & 44442 & 742,7 \\
\hline Kiskunfélegybáza & 32377 & 10 & & 19397 & 16,4 & 51774 & 810,7 \\
\hline Kiskunhalas & 29493 & 16 & 2 & 49798 & 22,2 & 79291 & 1567,7 \\
\hline Szeged & 160060 & 29 & 2 & 84296 & 23,2 & 244356 & 1920,2 \\
\hline Szentes & 31498 & 4 & & 9761 & 12,3 & 41259 & 619,7 \\
\hline Hódmezövásárhely & 48894 & 3 & 1 & 11397 & 19,2 & 60291 & 655,1 \\
\hline Makó & 25870 & 13 & & 23455 & 12,6 & 49325 & 671,2 \\
\hline Csongråd & 18686 & 6 & & 10606 & 13,9 & 29292 & 443,1 \\
\hline Békéscsaba & 64268 . & 14 & & 35718 & 24,5 & 99986 & 867,6 \\
\hline Gyula & 33317 & 13 & 2 & 38794 & 21,7 & 72111 & 959,0 \\
\hline Békés & 21759 & 5 & $l$ & 18191 & 10,9 & 39950 & 464,8 \\
\hline Mezỏkovácsháza & 7160 & 11 & 2 & 28157 & 14,1 & 35317 & 665,4 \\
\hline Orosháza & 32631 & 13 & 1 & 36255 & 15,7 & 68886 & 1067,8 \\
\hline Szarvas & 18248 & 5 & & 11299 & 10,6 & 29547 & 507,0 \\
\hline Gyomaendrőd & 15816 & 4 & $l$ & 29509 & 18,2 & 45325 & 897,2 \\
\hline Szeghalom & 10268 & 8 & & 24201 & 13,9 & 34469 & 785,4 \\
\hline Debrecen & 206882 & 35 & 6 & 136455 & 24,5 & 343337 & 2686,0 \\
\hline Berettyóújfalu & 15619 & 27 & 1 & 38738 & 21,0 & 54357 & 1183,3 \\
\hline Hajdúböszörmény & 31419 & 0 & & & & 31419 & 370,8 \\
\hline Hajdủnánás & 18711 & 2 & $l$ & 11845 & 8,3 & 30556 & 440,5 \\
\hline Hajdúszoboszló & 23102 & 4 & 1 & 13762 & 13,4 & 36864 & 556,6 \\
\hline Püspökladány & 16300 & 5 & & 19416 & 14,9 & 35716 & 627,2 \\
\hline Nyiregyháza* & 112998 & 55 & 6 & 151140 & 22,5 & 264138 & 1995,3 \\
\hline Fehérgyarmat & 8831 & 53 & & 34062 & 16,4 & 42893 & 797,6 \\
\hline Kisvárda & 17866 & 43 & 1 & 72792 & 14,2 & 90658 & 893,0 \\
\hline Mátészalka & 18191 & 30 & 2 & 55028 & 16,4 & 73219 & 708,0 \\
\hline Nyirbátor & 13122 & 17 & 1 & 27540 & 11,0 & 40662 & 629,1 \\
\hline Tiszalök & 5930 & 4 & 1 & 22689 & 10,4 & 28619 & 381,7 \\
\hline Vásárosnamény & 9074 & 27 & & 28258 & 12,5 & 37332 & 609,3 \\
\hline Szolnok & 77592 & 21 & 2 & 69652 & 17,8 & 147244 & 1257,6 \\
\hline Jászberény & 28230 & 13 & 1 & 31430 & 15,5 & 59660 & 725,9 \\
\hline Karcag & 22543 & 3 & & 9353 & 15,5 & 31896 & 596,7 \\
\hline Kisújszállás & 12884 & 4 & 2 & 25607 & 16,0 & 38491 & 781,0 \\
\hline Tiszaföldvár & 11472 & 9 & 2 & 27852 & 12,7 & 39324 & 524,8 \\
\hline Tiszafüred & 14326 & 13 & & 31149 & 18,3 & 45475 & 1081,2 \\
\hline Tôrökszentmiklós & 23168 & 11 & & 25655 & 19,4 & 48823 & 701,0 \\
\hline Mezõkövesd* & 17579 & 23 & & 30496 & 13,3 & 48075 & 806,7 \\
\hline Tiszaújváros & 17890 & 20 & 2 & 36444 & 14,0 & 54334 & 675,4 \\
\hline Heves & 11475 & 16 & & 29762 & 15,6 & 41237 & 791,6 \\
\hline Hatvan* & 23771 & 26 & 2 & 59850 & 14,0 & 83621 & 805,7 \\
\hline Cegléd & 36172 & 11 & & 42393 & 16,6 & 78565 & 803,3 \\
\hline Nagykórös & 26384 & 1 & & 1936 & 11,7 & 28320 & 295,2 \\
\hline Dabas & 15173 & 10 & & 27277 & 12,0 & 42450 & 649,8 \\
\hline Monor* & 19392 & 12 & & 47442 & 11,8 & 66834 & 426,6 \\
\hline Nagykáta* & 11936 & 9 & & 33001 & 12,8 & 44937 & 471,6 \\
\hline átlag & 33198 & 15 & & 37307 & 18,1 & 70505 & 870,5 \\
\hline relatív szórás & 1,17 & 0,83 & & 0,80 & 0,25 & 0,92 & 0,58 \\
\hline
\end{tabular}

Alföldi településeket vonzó külsö központok: Dunaújváros 6, Ráckeve 7, Gyöngyös 5, Eger 8,

Miskolc 5, Szerencs 4, Sárospatak 8, Sátoraljaújhely 5 vonzott alföldi település

* a vizsgált teruleten kívüli vonzott telepúlésekkel együtt

Forrás: Saját számítások. 
Kiss János Péter - Bajmócy Péter: Városi funkciójú központok és elméleti vonzáskörzeteik az Alföldön. Tér és Társadalom, 15. 2001. 1. 65-89. $p$.

A 2. modellben kétszer alakult ki ez a helyzet, amelyeknek speciális okai vannak. A központok köréből kieső legnagyobb város, Mezőtúr közelében (a kis Kétpón kívül) egyszerủen nem található $15 \mathrm{~km}$-nél közelebbi település. A szomszédos, nála valamivel kisebb városok (Szarvas, Gyomaendrőd, Tiszaföldvár, Törökszentmiklós, Kisújszállás) ezért - vonzáskörzetükkel együtt - népesebbek nála, így maga Mezőtúr a közúton hozzá legközelebb levő Gyomaendröd körzetébe került.

A másik kivételes eset Tiszavasvári, amelynek közvetlen környezetében nincsenek falvak, míg a hozzá legközelebbi város, a feleakkora Tiszalök az általa elvonzott három faluval éppen meghaladta Tiszavasvári lakosságát. A szelekció során a központok sorából kiesö Tiszavasvári ennek következtében maga is Tíszalökhöz került, s ezzel a tiszalöki „körzet” népessége elérte a 25 ezres határt. Tỉszalök a legkisebb népességú, vonzásközpontként megmaradt város, de az - egyébként a tiszavasvári KSH-kistérséggel teljesen azonos településkörre kiterjedő - körzet valódi központjának Tiszavasvári tekinthetö.

\section{A centrumok és a vonzásterületek mérete, típusai}

A vonzáskörzetek méretének szóródása a központokénál kisebb, de még így is igen jelentős, akár területüket, akár lakosságukat, akár településszámukat vesszük figyelembe (1. táblázat). A körzetek területük nagyságát tekintve a leghomogénebbek: az átlag közel kilencszáz $\mathrm{km}^{2}$, a relatív szórás 0,58 . A vonzott települések száma (átlagosan 15) és a vonzásterületek népességnagysága (átlagosan 37 ezer, a központtal együtt 72 ezer fö) alapján a különbségek jóval nagyobbak (a relatív szórások értékei $0,8-0,9$ körüliek), hiszen a gravitációs modellek által lehatárolt területi egységekben a különböző nagyságú települések véletlenszerúen koncentrálódnak. E jelentős mértékủ heterogenitás részletesebb elemzése révén az alföldi városi vonzáskörzetek sajátos csoportjai különíthetök el.

A településhálózati sajátosságok ismeretében nem meglepö a vonzáskörzeteket alkotó települések számának ingadozása. A három, legtöbb települést vonzó központ a kis- és középfalvas Szabolcs-Szatmár-Bereg megyében található (Nyíregyháza 55, Fehérgyarmat 53, Kisvárda 43), de Mátészalka és Vásárosnamény is az „élbolyba” került e jellemző tekintetében. Rajtuk kívül még (Békéscsaba kivételével) a megyeszékhelyeknek, illetve Bajának, valamint az Alföld peremén, részben már kisfalvas területeken elhelyezkedő központoknak (Berettyóújfalu, Hatvan, Mezőkövesd, Tiszaújváros) van húsznál több településböl álló vonzásterülete a modellben.

A másik végletet a vonzáskörzet nélküli Hajdúböszörmény, az egyetlen falut vonzó Nagykőrös, a két település központjaként számított Hajdúnánás, a 3-3 vonzott településsel rendelkező Hódmezővásárhely és Karcag, illetve a 4-4 települést vonzó Tiszalök, Kisújszállás, Gyomaendrőd, Hajdúszoboszló és Szentes képviselik - a korábban már említett, speciális helyzetü Tiszalököt és Gyomaendrődöt kivéve 
Kiss János Péter - Bajmócy Péter: Városi funkciójú központok és elméleti vonzáskörzeteik az Alföldön.

Tér és Társadalom, 15. 2001. 1. 65-89. p.

TÉT XV. évf. 2001 - 1

Városi funkciójú központok...

77

mind tradicionális, nagyhatárú mezővárosok. Felmerülhet a kérdés, hogy indokolt-e vonzáskörzetnek tekinteni ezeket a néhány településböl álló együtteseket, amelyeken belül a központnak általában hatalmas népességi, gazdasági stb. túlsúlya van. Megítélésünk szerint feltétlenül, hiszen a felsorolt mezővárosok - alföldi „specialitásként” - szinte kistérségnyi határukon beluil kisvárosi vonzáskörzetnek megfelelö népességet tömörítenek, amely önmagában elegendỏ a középfokú funkciók racionális mủködéséhez (Beluszky 1974). Így nincs alapos okunk annak feltételezésére, hogy lakóik más városokat vennének igénybe a középfokú funkciók zömének elérése érdekében.

Több meglepetéssel is szolgál a 2 . modellben számított gravitációs vonzáskörzetek területeinek, illetve lakosságainak áttekintése (1. táblázat). A körzetek nagysága ugyanis nem feleltethetö meg egyértelmüen a vonzásközpontok nagyságának - olykor jelentỏs eltérések adódnak közöttük -, s a számított lineáris korrelációs együtthatók értékei is csak legfeljebb közepes erősségü kapcsolatra utalnak. A számított vonzáskörzetek hierarchiája tehát nem feltétlenül követi a központok hierarchiáját.

A körzetek területét tekintve kiemelkedik ugyan a legnagyobb lakosságú Debrecen közel $2700 \mathrm{~km}^{2}$-es számított vonzásterülete, ám az utána következö (1600 és $2200 \mathrm{~km}^{2}$ közötti) kategóriában három megyeszékhely (sorrendben Kecskemét, Nyíregyháza és Szeged) után Baja és Kiskunhalas térsége következik. Az ezeket követö, 1000 és $1300 \mathrm{~km}^{2}$ közötti területü körzetek között (Szolnok, Gyula és Orosháza mellett) a régóta periférikus, elmaradott, városhiányos közép-tiszavidéki és bihari térség hiányközpontjainak (Tiszafüred, Berettyóújfalu) vonzásterülete is megtalálható. Átlagos, $500-1000 \mathrm{~km}^{2}$-es a modellben számított körzetek zöme (ide tartozik a megyeszékhelyek közuil Békéscsabáé is), míg a legkisebb $\left(300-500 \mathrm{~km}^{2}\right.$ közötti) körzetek a városi jogállású települések által uralt területeken találhatók (Nagykőrös, Hajdúböszörmény, Tiszalök, Monor, Hajdúnánás, Csongrád, Békés, Nagykáta).

A legérdekesebb eredményt a vonzott területek (központ nélkül számított) lakosságszámainak összevetése adja. Ennek alapján Nyíregyháza vonzásterülete a legnagyobb (151 ezer lakossal), kevéssel megelőzve a hozzá képest majdnem kétszer népesebb Debrecen körzetét (136 ezer fö). Ez azzal magyarázható, hogy Nyíregyházától északra és keletre hiányoznak a teljesértékủ középfokú szerepkör betöltésére alkalmas nagyobb városi centrumok, így a Nyírség fővárosára nemcsak megyeszékhelyként, hanem középfokú ellátó centrumként is az átlagost jóval meghaladó nagyságú feladat hárul ${ }^{10}$. A két északkelet-alföldi megyeszékhelyet jelentősen leszakadva követi Kecskemét, majd Szeged vonzásterülete (87, illetve 84 ezer fö). Kecskemét esetében (kisebb mértékü eltérést okozva) hasonló a helyzet, mint Nyíregyházánál: közelében keleti és nyugati irányban a középfokú funkciók teljes körét betölteni képes települések nem találhatók. Így Kecskemét - 
Kiss János Péter - Bajmócy Péter: Városi funkciójú központok és elméleti vonzáskörzeteik az Alföldön. Tér és Társadalom, 15. 2001. 1. 65-89. p.

Debrecenhez és Nyíregyházához hasonlóan - a községeken kívül több városi jogállású települést is magához vonz.

$\mathrm{Az}$ átlagot meghaladó lakosságszámú (38-73 ezer fős) vonzásterülettel még további tíz központ rendelkezik a modellben. Közülük Kisvárdáé a legnagyobb - az abszolút sorrendben az 5. -, miközben maga a város népessége alapján csak a 31. a modellben számításba vett 48 város közül. Kisvárda e kiugróan erős központi szerepkörét tehát egyértelmủen a környékbeli versenytársak hiányának „köszönheti”. E kategóriában szerepel még Baja és Szolnok (de hiányzik a megyeszékhelyek közül Békéscsaba), továbbá itt található a középvárosok egy része (Hatvan, Kiskunhalas, Cegléd és Gyula), a Kisvárdáéhoz hasonló helyzetü Mátészalka és Berettyóújfalu, valamint a budapesti agglomeráció peremén népes településekkel szomszédos Monor is.

A vonzásterületek leggyakoribb nagysága 18-36 ezer fö: 25 ilyen körzet adódott a modellben. A legkisebb vonzott népességgel (0-14 ezer fö) rendelkező központok mindegyike nagyhatárú hajdani mezőváros (Hajdúböszörmény, Nagykőrös, Karcag, Szentes, Csongrád, Szarvas, Hódmezővásárhely, Hajdúnánás, Hajđúszoboszló).

A vonzáskörzetek teljes (a központtal együtt számitott) lakossága feleltethető meg a leginkább a városok hierarchiájának (a 48 központra számított rang-korreláció értéke $r_{r a n g}=0,62$ ). A hét legnépesebb (egyúttal a 100 ezres határt elérö) körzet a hat megyeszékhelyé, illetve Bajáé, ezen belül az észak-alföldiek érzékelhetö „fölényével”. A következő, 60-90 ezres kategóriába egy kivétellel (Monor) a megyéjükön belül alközponti szerepkört betöltő közép- (Kiskunhalas, Cegléd, Gyula, Orosháza, Hódmezövásárhely, Jászberény) és kisvárosok (Kisvárda, Mátészalka, Hatvan) körzetei kerültek. A további 33 körzet 28-55 ezer lakosú, kistérségnyi terület, amelyek között kisvárosi térségek és „,alföldies” - egy közép(általában hajdani mezó)városból és néhány további településből álló - körzetek egyaránt elöfordulnak.

$\mathrm{Az}$ eddigiekben ismertetett jellegzetességeket még érzékletesebben mutatja a vonzott területek és a központok lélekszámának összevetése a számított vonzáskörzeteken belül. A modell szerint egy „átlagos” alföldi vonzáskörzetben a vonzott települések összlakossága éppen hogy csak (10\%-kal) meghaladja a vonzásközpont népességszámát, lényegileg tehát az Alföld lakosságának egyik fele központi szerepkörü városokban él, míg a másik fele az ezek által vonzott falvakban és kisvárosokban. Az átlag mögött azonban jelentős - és jellemző - különbségek húzódnak meg. A már többször említett Kisvárda körzetében a vonzott lakosság több mint négyszerese a központ lakosságának. 3 és 4 közötti aránnyal jellemezhető még azaz Kisvárdához hasonló, közeli potenciális versenytársak nélküli „hiányközpontnak” tekinthetö - a szintén Szabolcs-Szatmár-Bereg megyei Fehérgyarmat, Tiszalök, Vásárosnamény és Mátészalka is, míg az Alföld többi részén 
Kiss János Péter - Bajmócy Péter: Városi funkciójú központok és elméleti vonzáskörzeteik az Alföldön.

Tér és Társadalom, 15. 2001. 1. 65-89. p.

egyetlen esetben (Mezőkovácsháza) találunk ilyen szélsőséges értéket. Mindez immár sokadik bizonyítéka Szabolcs-Szatmár-Bereg megye az alfölditől jelentősen eltérő elméleti térkapcsolati rendszereinek, vonzásviszonyainak, amelynek három fö eleme: a nagyobbrészt kis- és középfalvas településszerkezet, Nyíregyháza kiemelkedö központi szerepköre és a megye alulfejlett városhálózata, ,,alulurbanizáltsága”.

Ugyanakkor még a központ népességszámát sem éri el, vagy haladja meg lényegesen a vonzott települések összlakossága (Nyíregyházát kivéve) a megyeszékhelyek, illetve a tradicionális mezővárosok többségének térségeiben (Püspökladány, Cegléd, Gyula, Jászberény, Orosháza, Törökszentmiklós, Makó, Békés, Hajdúnánás, Szarvas, Kiskunfélegyháza, Hajdúszoboszló, Csongrád, Karcag, Szentes, Hódmezövásárhely, Nagykörös, Hajdúböszörmény). Ezekben a körzetekben él az Alföld lakosságának valamivel több, mint fele.

A 2. modell alapján végzett különböző számításaink eredményeit összevetve a körzetek között jól elkülöníthető́k a sajátosan ,alföldi jellegű”, egy nagyobb (illetve néhảny esetben 2-3 kisebb) mezỏvárosból és néhány faluból álló egységek. Önálló típusként jelennek meg a nem igazán Alföld-specifikus, az ország más térségeiben meglevőkhöz hasonló kisvárosok - ezek altípusának tekinthetők a már említett szabolcs-szatmár-beregi városkörzetek -, valamint a megyeszékhelyek térségei. A modell alapján ez utóbbiak közé sorolható Baja is, mert körzetének mérete minden számított jellemző tekintetében a megyeszékhelyekéhez hasonló. Jelentősen elmarad ugyanakkor a többi megyeközpontétól Békéscsaba körzetének nagysága. A város megyeszékhelyi szerepköre természetesen elvitathatatlan, de önálló középfokú ellátási területe - a modell eredményei szerint - a sajátos közép-békési középváros-együttes létéből következöen nem túl nagy, megyéjén belül Gyuláéhoz és Orosházáéhoz hasonló nagyságrendủ.

\section{A városi funkciók elérhet ösége: centrum-közeli és periférikus települések}

Érdemes áttekinteni, hogy mekkora a modellben az egyes vonzott településekre ható vonzóerő nagysága (4. ábra). Nyilvánvaló ugyanis, hogy a városi szolgáltatások legkedvezőbb elérésére az erősen vonzott (azaz valamely nagyvároshoz közel fekvő) településeken van a legjobb lehetőség, s a vonzerö csökkenésével ezek választéka egyre szúkül, és/vagy elérésük egyre időigényesebb, drágább lesz. A gravitációs modell módszeréböl következően az azonos erővel vonzott települések elméletileg koncentrikus körökbe rendeződnek a vonzáscentrumok körül. Az Alföld speciális településhálózata következtében azonban a gyakorlatban ezek a körök jelentősen torzulnak, legtisztábban a régió nagyobb városai - Debrecen, Szeged, de leginkább Nyíregyháza - környékén fedezhetők fel. Az alföldi kisvárosok gyenge vonzóereje miatt viszont körülöttük igencsak kusza rajzolatú a vonzáserősségeket bemutató ábra. 
Kiss János Péter - Bajmócy Péter: Városi funkciójú központok és elméleti vonzáskörzeteik az Alföldön. Tér és Társadalom, 15. 2001. 1. 65-89. p.

80 Kiss János Péter - Bajmócy Péter

TÉT XV. évf. 2001

4. ÁBRA

A központok vonzásának erössége az egyes településekre a 2. modellben (azonos lakosságú ötödök)

(The Strength of Gravitation for the Individual Settlements in Model 2. - Quintiles

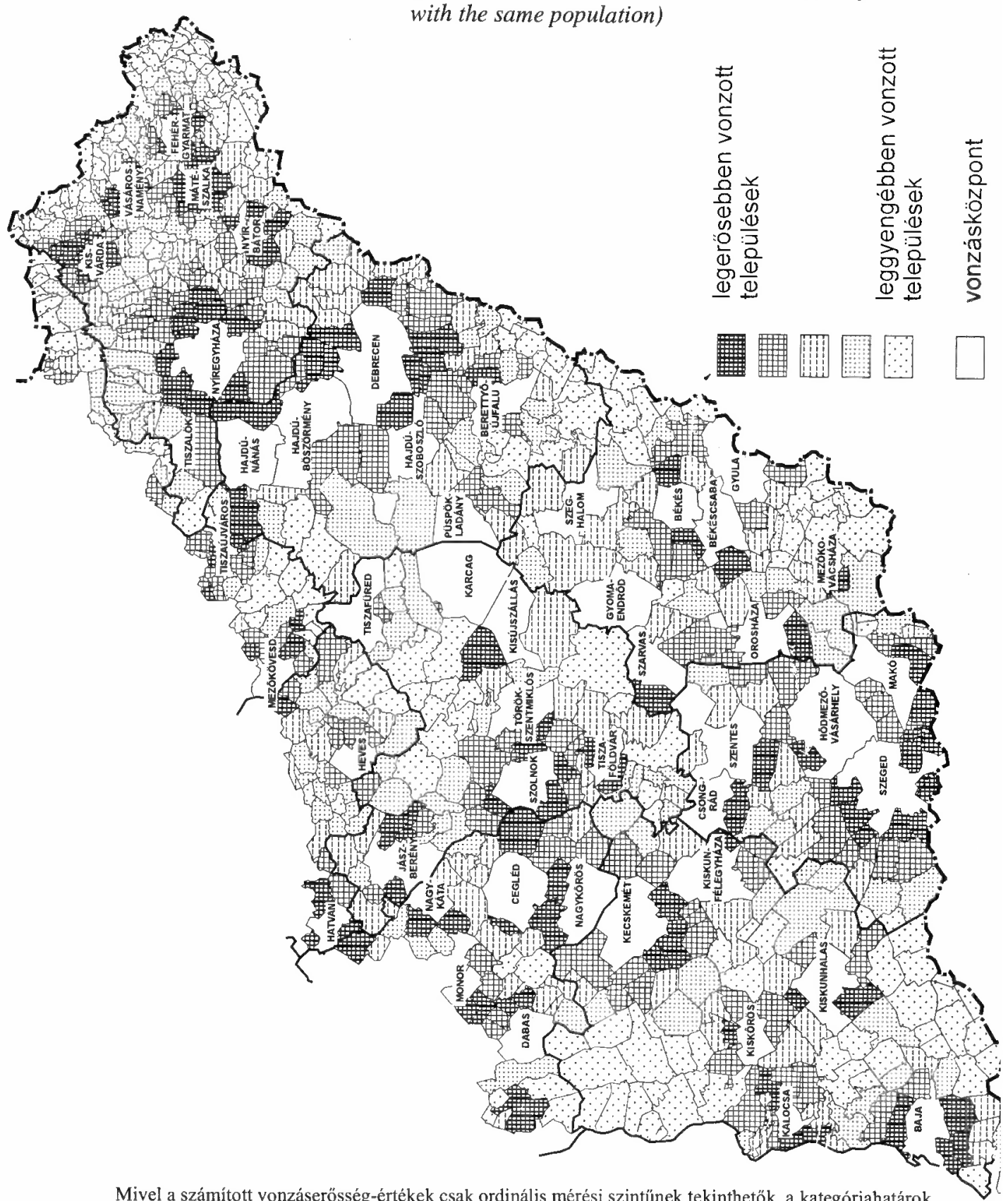

Mivel a számított vonzáserösség-értékek csak ordinális mérési szintủnek tekinthetők, a kategóriahatárok pontos értékeinek megadása felesleges, sőt adott esetben félrevezető lett volna.

Forrás: Saját szerkesztés. 
Kiss János Péter - Bajmócy Péter: Városi funkciójú központok és elméleti vonzáskörzeteik az Alföldön.

Tér és Társadalom, 15. 2001. 1. 65-89. p.

TÉT XV.évf. 2001

Városi funkciójú központok...

81

A legnagyobb összefüggő, erősen vonzott térségek az Alföld nagyvárosi tömörülései (Szeged-Hódmezővásárhely-Makó-Orosháza, KecskemétNagykörös-Cegléd-Szolnok, Debrecen-Nyíregyháza) körül helyezkednek el. A legerösebben vonzott, nagyobb városok körüli települések (illetve e városok jogilag nem önálló, de a városközponttól távolabbi részei) adják a szuburbanizáció potenciális területét. A legkevésbé vonzott térségek többsége pedig empirikusan is bizonyítottan társadalmi-gazdasági szempontból elmaradott terület, külső (Bodrogköz, Szatmár-Bereg, Bihar, Dél-Békés, Bácska) vagy belsö (KözépTiszavidék, Borsodi-Mezőség, Solt környéke) periféria. Érdemes megemlíteni, hogy bár egyértelmü korrelációs kapcsolat nincs - a leggyengébben vonzott településkör átlagnépessége a legkisebb, $\mathrm{s}$ az erösebben vonzott települések felé haladva egyre inkább emelkedik az átlagos lélekszám. A települési és területi elönyök, illetve hátrányok tehát gyakran halmozottan jelentkeznek az alföldi városközi térben.

A kistérségi centrumok elérhetőségének legfontosabb jellemzöje azonban gyakorlati (költség, idő stb.) szempontból az adott településtől való (közúti) távolságuk. Az ez alapján kirajzolódó területi kép (5. ábra) némileg eltér az elözötöl. A centrumokhoz legközelebbi települések az Alföldön a kisvárosok körül találhatóak, mert a nagyvárosok, illetve számos tradicionális alföldi mezöváros közigazgatási határa olyan nagy, hogy emiatt pl. Debrecen, Kecskemét, Szeged, Szolnok, Karcag, Hódmezővásárhely, Cegléd stb. városközpontjától $10 \mathrm{~km}$-es közúti távolságon belül egyetlen önálló község sem található. E legbelsö gyürü csak az apró- és kisfalvas környezetü Mátészalka, Fehérgyarmat, Nyírbátor és Vásárosnamény szomszédságában mondható teljesnek, s e tekintetben a tipikus alföldi városok közül legfeljebb Baja hasonlítható hozzájuk. A gravitációs centrumtól legtávolabbi $(30 \mathrm{~km}$ nél messzebb levö) települések általában valamelyik nagyváros elméleti vonzáskörzetébe tartoznak, ám valójában centrumhiányos térségben fekszenek (Kunszentmiklós, Bácsalmás térsége, ÉK-Békés). Számuk azonban nem túl nagy (30$40 \mathrm{~km}$-re a vonzáscentrumtól $72,40 \mathrm{~km}$-nél messzebb mindössze 20 település van), s meglehetősen elszórtan helyezkeđnek el. Ennek tükrében elgondolkodtató, hogy az Alföld periférikus térségeinek többsége nincs is túl messze vonzáscentrumától (20-40 km). E perifériák helyzetének javítása tehát nem új központok kialakítását, várossá nyilvánításokat tesz szükségessé, hanem alapvetően a meglevő kisvárosi centrumok funkcionális megerỏsítése által képzelhetỏ el.

Az egyes vonzott településeknek a központjuktól való átlagos távolsága 8 és 28 $\mathrm{km}$ között szóródik, $\mathrm{s}$ az alföldi átlag kifejezetten kedvezö: csak $18 \mathrm{~km}$ (1. táblázat). A legnagyobb értékek a megyeszékhelyek (és Baja) körzeteiben tapasztalhatók, ami logikus is, hisz e városok „tömege” a legnagyobb, vonzásuk így távolabbi településeket is elér. (Ezek lakóit persze valószínüleg kárpótolja a hosszabb utazásért a megyeszékhelyeknek az átlagosnál jóval kedvezőbb közlekedési elérhetösége és szolgáltatásaik körének bővebb választéka.) 
Kiss János Péter - Bajmócy Péter: Városi funkciójú központok és elméleti vonzáskörzeteik az Alföldön. Tér és Társadalom, 15. 2001. 1. 65-89. p.

82 Kiss János Péter - Bajmócy Péter

TÉT XV. évf. 2001 - 1

\section{5. ÁBRA}

A vonzott települések közúti távolsága gravitációs vonzásközpontjuktól

(The Road Distances of Gravitated Settlements from their Gravitation Centres)

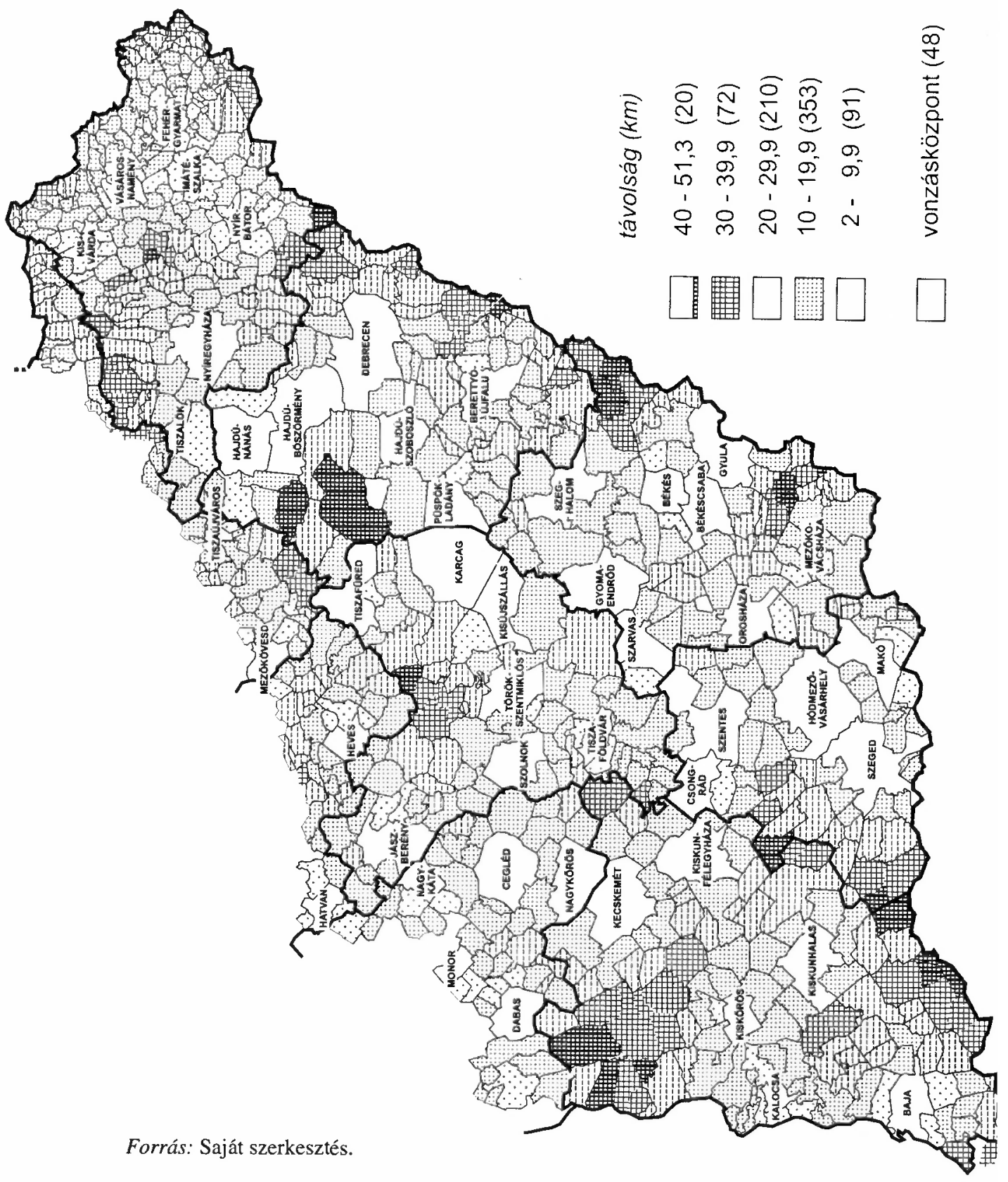


Kiss János Péter - Bajmócy Péter: Városi funkciójú központok és elméleti vonzáskörzeteik az Alföldön.

Tér és Társadalom, 15. 2001. 1. 65-89. $p$.

TÉT XV. évf. 2001 @ 1

Városi funkciójú központok...

83

A kis- és középvárosok esetében azonban az összefüggés már korántsem ilyen egyértelmü (a korrelációs együttható csak 0,5 -es értékü). ${ }^{11}$

\section{A statisztikai kistérségi beosztás a modell tükrében}

A modellszámítás eredményeként kapott elméleti vonzásközpontokat és -körzeteket érdemes összevetni az Alföld területén jelenleg létező - így a gyakorlatban megvalósuló vonzáskörzeti kapcsolatokat is jelentös mértékben meghatározó - hivatalos közigazgatási, illetve statisztikai-területfejlesztési egységekkel és központjaikkal. A KSH statisztikai kistérség-beosztását alapul véve az általunk vizsgált területen („Alföld”) 66 körzet települései találhatók. Ezek közül pontosan 50 térség teljes egészében a vizsgált területen belül helyezkedik el, további ötnek pedig az Alföldön található a központja és területének jelentős része. Ezen 55 körzet között van Bács-Kiskun, Békés, Csongrád, Jász-Nagykun-Szolnok, Hajdú-Bihar és Szabolcs-Szatmár-Bereg megyék valamennyi kistérsége, valamint Pest megyéből a ceglédi, dabasi, nagykátai és monori, Hevesből a hevesi, hatvani és füzesabonyi, Borsod-Abaúj-Zemplénböl pedig a tiszaújvárosi és mezőkövesdi statisztikai körzet. Minthogy 2. modellünkben 48 alföldi vonzásközpontot találtunk, elmondható, hogy a kétféle beosztás hasonló nagyságú egységekre („kistérségekre”) osztotta az Alföld területét. A vonzáskörzetek méretének (terület, összlakosság, vonzott lakosság) relatív szórása is hasonló nagyságrendü, bár a KSH-kistérségeké valamivel kisebb, s ez arra utal, hogy a kistérségek kialakításakor a viszonylagos méretbeli homogenitásra is törekedtek a funkcionális (vonzáskörzeti típusú) együvé tartozás biztosítása mellett.

A központok köre és térségeik kiterjedése már nagyobb mértékben eltér egymástól a kétfajta körzetbeosztásnál (3. ábra). Ennek legfontosabb oka az, hogy a KSH-körzetek nem léphetik át a megyehatárokat, míg a központok vonzása - a gravitációs modellben és a valóságban egyaránt - nem feltétlenül korlátozódik megyéjük területére. A legszélsőségesebb eset Hatvané, amely négy megyéből (Nógrád, Heves, Pest, Szolnok) vonz településeket a modellben, de Jászberény, Tiszafüred, Baja, Kecskemét körzete is három megyére terjed ki, további 19 alföldi központ gravitációs vonzásterülete pedig egy megyehatáron nyúlik át. Részben ebből következik - egyúttal további különbségeket is okoz -, hogy a 48 alföldi vonzáscentrum és az 55 kistérségi központ közül csak 42 azonos $^{12}$ : hat város csak a modellben szerepel központként (Gyula, Békés, Gyomaendröd, Hajdúnánás, Nagykörös, Kisújszállás), 13 város pedig, noha kistérségközpont, a 2. modellben nem vonzáscentrum (Bácsalmás, Kiskunmajsa, Kunszentmiklós, Jánoshalma, Kistelek, Mórahalom, Sarkad, Balmazújváros, Polgár, Füzesabony, Csenger, Nagykálló, Baktalórántháza). Egyetlen megyében sem azonos a statisztikai kistérségközpontok és a gravitációs vonzáscentrumok köre. Különösen nagy az eltérés Bács-Kiskunban (tíz kistérség - hat vonzáskörzet), Szabolcs-Szatmár- 
Kiss János Péter - Bajmócy Péter: Városi funkciójú központok és elméleti vonzáskörzeteik az Alföldön.

Tér és Társadalom, 15. 2001. 1. 65-89. p.

84 Kiss János Péter - Bajmócy Péter

TÉT XV. évf. 2001

Beregben (tíz kistérség - hét vonzáskörzet) és Békésben (hat kistérség - nyolc vonzáskörzet).

A 3. ábráról pontosan megállapíthatók a kétfajta területi beosztás hasonlóságai és különbségei. Teljes azonosság csak két esetben mutatkozik (Kiskunfélegyháza, illetve Tiszavasvári-Tiszalök körzete), és viszonylag kicsi az eltérés Makó, Fehérgyarmat, Vásárosnamény, Törökszentmiklós körzetei és statisztikai kistérségei között is. Kistérsége területét teljes egészében lefedö, de továbbj területekre is kiterjedő számított vonzáskörzettel rendelkezik Szeged, Kecskemét, Debrecen, Baja, Fehérgyarmat, Kisvárda, Csongrád, Monor, de egy-két településtől eltekintve alapvetően ebbe a típusba tartozik Szolnok, Nyíregyháza, Kiskunhalas, Hatvan, Mezőkövesd és Orosháza is.

A 13, gravitációs vonzásközpontként nem szereplö statisztikai kistérségközpont körzeteinek egy része a modellben szinte teljes egészében egy nagyobb centrum vonzáskörzetéhez csatlakozik (Kistelek és Mórahalom körzete Szegedhez, Bácsalmásé Bajához, Kiskunmajsáé és Jánoshalmáé Kiskunhalashoz, Sarkadé Gyulához, Csengeré Mátészalkához, Nagykállóé és Baktalórántházáé Nyíregyházához), míg a többiek területén több szomszédos központ „osztozik”. A modellben szereplő központok közül néhánynak lényegesen kisebb a gravitációs vonzásterülete, mint statisztikai kistérsége (Kiskörös, Szentes, Mezőkovácsháza, Nagykáta, Püspökladány, Tiszaföldvár). Egyes esetekben (Közép-Békés, Hajdúböszörmény) a KSH-kistérség területe több önálló gravitációs vonzásterületre darabolódott, a leggyakrabban pedig a kétfajta körzetbe tartozó települések köre jelentősen eltér egymástól.

\section{Alföldi sajátosságok a modellben: „átmeneti” kisvárosok, többcentrumú körzetek}

A különbözö empirikus vonzáskörzet-kutatások egybehangzó eredménye szerint az Alföldön különösen sok olyan kisváros van, amelyek, ha nem is teljes értékü központok, de rendelkeznek több-kevesebb középfokú funkcióval, amelyekkel néhány környezö település ellátását is biztosítják. Egyes vélemények szerint e kisvárosok külön hierarchiaszintet alkotnak. Mindezt a modellszámítások eredményei is alátámasztják. Már a 2. modell kidolgozása során mintegy tucatnyi olyan kisvárosi vonzáskörzet akadt, amelynek 20-25 ezer fós lakossága - nem utolsósorban a központ kis népessége miatt - csak kevéssel maradt el a küszöbértéktöl. Ezek egy része nagyobb városok vonzásterületének peremén található, így a szelekció során térségükkel együtt e centrumokhoz kerültek (Bácsalmás Bajához, Jánoshalma és Kiskunmajsa Kiskunhalashoz, Sarkad Gyulához, Tótkomlós Orosházához, Balmazújváros, Hajdúhadház és Nyíradony Debrecenhez, Ibrány Nyíregyházához, Újszász Szolnokhoz). 
Kiss János Péter - Bajmócy Péter: Városi funkciójú központok és elméleti vonzáskörzeteik az Alföldön.

Tér és Társadalom, 15. 2001. 1. 65-89. $p$.

TÉT XV. évf. 2001 - 1

Városi funkciójú központok...

85

A többi hasonló kisváros viszont hozzá képest alig nagyobb központ vonzásterületébe olvadt, amely épp ennek köszönhetően lépte át a határértéket (Kiskörös, Kisújszállás, Tiszaföldvár, Tiszalök, Hajdúnánás, Mezőkovácsháza). Mindez az alföldi településfejlődés már többek által megfogalmazott sajátos következményére utal: az egymással alapvetỏen mellérendelő viszonyban lévő szomszédos kisvárosok térségi funkcióinak megosztására, saját lakosságuk és a környező falvak ellátásában az együttmúködés, szükségességére (MezőkovácsházaMezőhegyes-Battonya, Tiszavasvári-Tiszalök, Kisújszállás-Túrkeve-Kunhegyes, Hajdúnánás-Hajdúdorog, Kiskőrös-Kecel-Soltvadkert, Tiszaföldvár-Martfü). ${ }^{13}$

E sajátosságok egy újabb modellvariáns kiszámítását tették indokolttá (2/b. modell). Ennek során a vonzott települések lakosságát kétszeresen számítva a 30 ezer fös értéket tekintettük a vonzáskörzeti népesség alsó határának. (A szelekció során a „megszüntetett” vonzáskörzetek városainak, mint vonzott településeknek a népességét is kétszeresen vettük figyelembe). Ezen - a kisebb városok számára „kedvezőbb” - számítási módszer létjogosultságát az adja, hogy a vonzáskörzetek létezésének épp a kisvárosi térségekben van a központ számára is meghatározó jelentősége. A nagyobb városok ugyanis önmagukban is megfelelö nagyságú piacot jelentenek az egyes középfokú funkciók müködéséhez, míg a kisvárosok csak vonzott településeikkel együtt érik el ugyanezt.

A 2/b. modellben így 60 alföldi és 8 külső központ vonzáskörzeteit határoltuk el a vizsgált területen. A 60 alföldi centrum közé került valamennyi, a 2. modellben szereplö központ is. A „különbséget” jelentó 12 város közül 11 megegyezik azokkal, amelyeknek körzete a 2 . modellben a legjobban megközelítette a 25 ezres küszöböt. A kétféle, lényegesen eltérő módszerrel kapott eredmény e nagyfokú egyezése arra utal, hogy nemcsak a teljes értékü középfokú központok, hanem a részleges középfokú központi szerepkört betöltő kisvárosok csoportja is karakterisztikusan elkülönül az alföldi városok mezőnyében. A kismértékủ eltérést Csenger (illetve a külső központok közül Tokaj) jelentették, amelyek ugyan kis lélekszámúak, de a szomszédos városoktól távol helyezkednek el, így viszonylag sok telepulést vonzanak. Hozzájuk hasonló Solt szerepe is. A többi ilyen „részleges” centrum speciális helyzetét egy-egy szomszédos nagy- vagy kỏzépvároshoz való viszonya határozza meg. Ezek (Balmazújváros, Hajdúhadház, Nyíradony, Ibrány, Kistelek, Újszász, Bácsalmás, Sarkad, Tótkomlós, Kunhegyes) vonzása a nagyobb centrum (Debrecen, Nyíregyháza, Szeged, Szolnok, Baja, Gyula, Orosháza, nagykun városok) ,árnyékoló” hatása miatt csak az attól ellentétes irányban tud érvényesülni, s e kisvárosok népessége így már éppen nem elegendő a teljesértékủ központtá váláshoz. A gyakorlatban mindez úgy nyilvánul meg, hogy saját maguk és vonzott telepúléseik számára is a központi funkciók egy részét a nagyobb város biztosítja. $\mathrm{E} 12$ kisváros szerepének megítélésében az állami településpolitika is bizonytalan: a 2. modellben is szereplö központoktól eltérően 
Kiss János Péter - Bajmócy Péter: Városi funkciójú központok és elméleti vonzáskörzeteik az Alföldön.

Tér és Társadalom, 15. 2001. 1. 65-89. $p$.

86 Kiss János Péter - Bajmócy Péter

TÉT XV. évf. 2001 - 1

valamennyiük 1986 és 1997 között kapta csak meg a városi rangot, és mindössze öt (Csenger, Bácsalmás, Kistelek, Sarkad, Balmazújváros) központja valamely KSHkistérségnek.

\section{A modellvizsgálat tanulságai és korlátai}

Modellszámításaink eredményeinek alapján legfontosabb következtetéseink az alábbiakban összegezhetök:

1) A választott módszer révén nem csupán az elméleti vonzáskörzetek nagyságát, hanem - az eredményeket alapvetöen meghatározó - központok körét is sikerült mindenféle prekoncepciót mellözve, objektív módon meghatározni. Így feltételezhető, hogy - a korábbi hazai alkalmazásoktól (Lackó 1978; Beluszky 1984) eltéröen - modellünk jól közelíti a valódi vonzásviszonyokat a sajátos és heterogén településrendszerrel rendelkezö Alföldön is.

2) Az empirikus kutatások eredményeivel való egybevágóság jórészt igazolta, hogy egy város térségi szerepköreinek kialakulása nem a központ, hanem a központtal együtt számított ellátott terület nagyságától fủgg.

3) A részben eltérö módon elkészített háromféle modellvariáció alapján - kevés számú speciális esettöl eltekintve - meglehetősen egyértelmủen kirajzolódott az elméletileg alátámaszthatóan teljes körú, illetve részleges térségi központi szerepkörrel rendelkező alföldi városok köre. A vonzáskörzetek között kvantifikálható módon elkülönülttek az alföldies típusú (mezővárosi, illetve több kisközponttal is rendelkezö), illetve a klasszikus nagyvárosi (megyeszékhelyi) és kisvárosi körzetek.

Eredményeinkböl ugyanakkor csak nagy óvatossággal szabad gyakorlati következtetéseket levonni. Ennek oka alapvetően az, hogy a bonyolult térszervezö folyamatok és társadalmi mozgások csupán két tényező (tömeg, távolság) mechanikai összefüggésére való visszavezetése a valóság nagyfokú leegyszerüsítését jelenti. Egyszerüsítettük a vonzáskapcsolatoknak a valóságban sokszor igen bonyolult rendszerét azáltal is, hogy minden vonzott települést teljes egészében egy és csakis egy központhoz soroltunk a számítás során, holott az Alföldön különösen gyakran előfordulnak többirányú vonzódások ${ }^{14}$ : egy telepưlés közel azonos intenzitással, vagy másodlagosan, harmadlagosan más központokhoz is kapcsolódhat, s így léteznek ,átmeneti” vonzásterületek is. ${ }^{15}$ A tömeg, távolság, kitevő megválasztásában rejlö - korábban ismertetett - hibaforrásokon kívül a nagy területủ vagy jelentékeny számú külterületi lakossággal rendelkező alföldi települések esetében problematikus a teljes népesség egy ponthoz (a település középpontjához) való rendelése is a modellben. Az aktuális népességszámokat alapul véve az egyes központok számított vonzásterületei akár évrỏl-évre változhatnak (Papp 1981), holott a központi szerepkörök és vonzások rendszerének átalakulása ennél jóval lassúbb ütemü, s hosszabb megelöző időszak hatásait 
Kiss János Péter - Bajmócy Péter: Városi funkciójú központok és elméleti vonzáskörzeteik az Alföldön.

Tér és Társadalom, 15. 2001. 1. 65-89. p.

tükrözi vissza. Végül érzéketlen a modell az egyes funkciótípusok eltérö (s gyakran nem is konzisztens) központ-állományának és hatásterületeinek különbségeire is. (Az „ágazati” vonzáskörzetek összevont modellezése, komplex egységként való értelmezése ugyanakkor persze elönyt is jelent.)

Számos tanulsággal járhat azonban az ilyen, elméleti alapokon lehatárolt vonzáskörzetek összevetése a gyakorlatban kialakult, empirikusan feltárt térkapcsolati rendszerekkel. Ennek alapján elkülöníthető, hogy a különböző vonzáskörzetek létezésében mekkora a központok nagyságával és elhelyezkedésével összefüggö tényezök szerepe, valamint, hogy az elméletileg számított és a valóságban létezö térkapcsolati rendszerek eltérései mennyiben köszönhetők az igazgatási-adminisztrativ határok torzító hatásának, miben és mennyire nyilvánul meg bennük a számszerüleg nem megragadható minőségi különbségek, illetve egyéb, irracionális tényezök (történelmi hagyományok, rokoni, etnikai kapcsolatok stb.) hatása.

\section{Jegyzetek}

'Az egyes központokhoz vezetö legrövidebb utat autóatlasz, illetve számitógépes útvonal-optimalizáló program segítségével határoztuk meg, az 1998. év eleji közforgalmú úthálózatot alapul véve. A folyókon való áthaladásnál csak az állandó hidakat vettikk figyelembe.

${ }^{2}$ Az alacsonyabb státuszủ rétegek általában kevésbé mobilak, így az ő vonzáskörzeteik kijelölésében nagyobb kitevővel kell, hogy szerepeljen a távolság. A vidéki kőzéposztály és a falusi-kisvárosi elit mozgásai gyakoribbak, a minőségi szolgáltatásokat keresve hajlandók a távolabbi, nagyobb városokba is elutazni, igy az ö esetükben a távolság kitevöje szükségképpen kisebb. Mindez végsö soron azt jelenti, hogy a különbözö társadalmi csoportok vonzáskörzetei is többé-kevésbé eltérnek egymástól (Beluszky 1974).

${ }^{3}$ A gravitációs vonzáskörzetek meghatározásának egyik lehetséges módja - amit a módszer korábbi hazai alkalmazói (Lackó 1978; Papp 1981; Süli-Zakar 1996) is választottak -, hogy n-ed fokú egyenlet segítségével meghatározzák azt a görbét, amelyre a két szomszédos központ vonzásának eb̉ssége egyenló, azaz tulajdonképpen a vonzáskörzethatárokat adják meg. Ebben az esetben azonban csak kettö, esetleg három lehet a hatványkitevö értéke, hiszen csak ilyen fokú egyenletekre létezik a gyakorlatban is használható megoldóképlet. Az általunk választott számítási mód jóval egyszeuibb, ugyanakkor jóval több lehetőséget nyújt. Ennek során valamennyi településre kiszámítjuk az összes központ vonzóerejét, és mindegyiküket az öt legerösebben vonzó központhoz soroljuk be. İgy, noha a határvonal elméleti helye csak közelító pontossággal adható meg, mégis tetszỏleges pontról (településről) bármely kitevő esetén egyértelmüen eldönthetö, hogy melyik központ elsödleges vonzáskörzetéhez tartozik.

${ }^{4}$ Az elméletileg várható vonzáskörzetek - itt nem részletezett matematikai összefüggések miatt - vagy körök (ún. Apollóniusz-körök), vagy pedig olyan síkidomok, amelyeket a szomszédos központok vonzásterületeit elválasztó körvonalak bizonyos összefügø̋ darabjai (illetve a vizsgált terület pereme) határolnak.

${ }^{5}$ Ennek sok esetben ,fizikai" akadályai vannak. Az alföldi településeknek immár hetedrésze, ezen belü egyes tájakon harmada-ötöde ugyanis városi jogállású, ráadásul egy részuk egymás mellett található, vagy láncszerüen határos egymással (a leghosszabb a Kiskunfélegyháza-Szarvas-KarcagHajdúszoboszló-Nyíregyháza-Ibrány várossor, számos további elágazással). Így több városnak is alig akad községi jogállású szomszédja, ami ebben a modellvariánsban nem teszi leheb́vé az empirikus elemzésekkel is összevethetö vonzásterületek elhatárolását. 
${ }^{6}$ Ezek együttese - bár a gyakorlatban a különbözö funkciótipusok általában nem teljesen konzisztensen jelennek meg az egyes központokban - a városhierarchia alapja.

${ }^{7}$ Az optimum elméleti meghatározása kétféle úton is lehetséges. Az egyik lehetőség szerint ez az ideális érték nem más, mint a figyelembe vett központi funkciók minimális piacméreteinek súlyozott átlaga. Lehetséges (az elözőnél kisebb értéket produkáló) megoldás azonban az is, amikor ezt az összevont értéket úgy képezzük, hogy - valamely matematikai mérték alapján - e pont megadott környezetében a lehetô legtöbb középfokú központi funkció minimális piacmérete legyen megtalálható.

${ }^{8}$ A relativ szórás - a sokaság valamely számszerü jellemzője szórásának és átlagának hányadosa - az egyik leggyakrabban használt koncentrációs méröszám.

${ }^{9} \mathrm{Az} 1986$ előtt is városi jogállással rendelkezett alföldi települések között viszont csak kettó olyan van, amely a modellben nem szerepelt vonzásközpontként (Mezötúr, Túrkeve).

${ }^{10}$ Nyíregyháza e sajátos szerepét már a hetvenes évek elején empirikusan elemezte Beluszky Pál (Beluszky 1974). Adatokkal igazolható (pl. a város lakosságához képest kiugró kiskereskedelmi forgalom, bankfiókszám, kórházi ágyszám stb.), hogy a helyzet azóta e téren lényegileg nem változott.

"Ennek oka ismét csak az alföldi telepuiléshálózat sajátossága: a vonzáskörzetek alakjának az egymással szomszédos városi centrumok hatásából eredö torzulása, valamint az, hogy a zömmel nagyfalvakból álló és ritka településhálózat miatt nagyobb a jelentősége annak, hogy egy-egy konkrét település melyik központhoz kerul.

${ }^{12}$ Kistérségi központnak a KSH-körzetek legnépesebb városait tekintettük, ami egy esetben tér el a hivatalos megjelöléstöl. A kunszentmártoni körzet legnépesebb városa ugyanis Tiszaföldvăr. A tiszalöki vonzáskörzet központjának pedig a legnagyobb népességủ Tiszavasvárit tekintettuk.

${ }^{13}$ llyen viszony eggyel magasabb hierarchiaszinten, a középvảrosok között is előfordul (Közép-Békés, nagykun városok, hajdúvárosok, Csongrád-Szentes, Gyomaendrőd-Mezőtúr-Szarvas, CeglédNagykörös).

${ }^{14}$ Mindez persze csak az adminisztrativ kơrzethatárokkal nem rögzített, „spontán” választásokon alapuló térkapcsolatokra igaz. A bíróságok, munkaügyi központok, földhivatalok, rendỏrségi igazgatási központok stb. ellátási területeinek határai egyértelmủen rögzítettek, amelyek igy közvetlenül is összevethetők a gravitációs vonzáskörzethatárokkal. Hasonló a helyzet a megyeszékhelyek vonzáskörzetei és a megyék viszonyát tekintve is (Bajmócy-Kiss 1999).

${ }^{15}$ Ezek figyelembevételére a modellen belül megvan az elméleti lehetőség. Lehetséges eljårás ugyanis, hogy minden, nem kőzponti településre kiszámítsuk valamennyi centrum vonzóerejét, és ezeket összegezve megadható a különbözö centrumok részesedẻse az egyes településekre ható vonzeröböl. Ha pedig ennek megfelelően a vonzott települések lakosságát is megosztjuk a centrumok között, módosulhat a központok által ellátott lakosságszám, sőt akár még a centrumok köre is. Mindez azonban rendkívül sok számítást igényelne, és a vonzáskörzeti térképet általában csak kis mértékben változtatná meg.

\section{Irodalom}

Bajmócy P.-Kiss J. (1999) Megyék, régiók és központjaik - modellek tükrében. - Tér és Társadalom. 1-2.31-51.0.

Becsei. (1996) A kistérségi területi rendszer elveiröl. - Tér - Gazdaság - Társadalom. Huszonkét tanulmány Berényi Istvánnak. MTA FKI, Budapest. 162-174. o.

Beluszky P. (1967) A magyar városok központi szerepköre. - Statisztikai Szemle. 6. 543-563. o.

Beluszky P. (1974) Nyíregyháza vonzáskörzete. - Földrajzi Tanulmányok 13. Akadémiai Kiadó, Budapest.

Beluszky P. (1984) Vonzáskörzetek lehatárolása gravitációs modellekkel. Matematikai és statisztikai módszerek alkalmazási lehetôségei a területi kutatásokban. Földrajzi Tanulmányok 19. - Sikos T.T. (szerk.), Akadémiai Kiadó, Budapest. 167-171., 184-185.o.

Dicken, P.-Lloyd, E.P. (1984) The modern western society. Harper and Row, New York. 
Kiss János Péter - Bajmócy Péter: Városi funkciójú központok és elméleti vonzáskörzeteik az Alföldön.

Tér és Társadalom, 15. 2001. 1. 65-89. p.

TÉT XV. évf. 2001

Városi funkciójú központok...

89

Lackó L. (1978) Települések vonzásteruiletének meghatározása egymásrahatási modell segítségével. Földrajzi Értesitö. 1. 31-43. o.

Meyer, I.-Huggett, R. (1981) Settlements. Harper and Row, London.

Nemes Nagy J.-Piros Gy. (1984) Térbeli népesség- és anyagáramlások vizsgálata gravitációs modellel. Matematikai és statisztikai módszerek alkalmazási lehetöségei a területi kutatásokban. Földrajzi Tanulmányok 19. - Sikos T.T. (szerk.), Akadémiai Kiadó, Budapest. 171-175. o.

Papp A. (1981) Debrecen vonzáskörzete. - Alföldi Tanulmányok. 177-201. o.

Süli-Zakar I. (1996) A régió: földrajzi integráció. - Tér - Gazdaság - Társadalom. Huszonkét tanulmány Berényi Istvánnak. MTA FKI, Budapest. 139-159. o.

\section{URBAN CENTRES AND THEIR THEORETIC SPHERES OF INFLUENCE IN THE GREAT HUNGARIAN PLAIN}

\section{JÁNOS PÉTER KISS -PÉTER BAJMÓCY}

In this paper we tried to border the spheres of influence of the towns in the Alfold (Great Hungarian Plain). Because of the special settlement network of the Alföld (towns with very large administrative area, lack of villages, tanya system, etc.) the every day connections between the settlements are very difficult, and because of it, it was interesting to examine these connections in a theoretical way, with the gravity model. With the gravity model we could border the spheres of influences of the towns, as well as the ,real" or functional urban centres of the Alföld, those centres, which have enough villages which in its sphere of influence. It was interesting to compare the theoretical spheres of influences and the statictical micro-regions, and compare the theoretical spheres of influence together by area, population and the number of settlements. We could use different model-variations with the distances counted by air or on route, and different variations to specify the ,real" urban centres. 